\title{
POESÍA E FICCIÓNS DO EU
}

\author{
POETRY AND FICTION OF THE SELF
}

\section{Pilar Pallarés}

\begin{abstract}
Resumo: Partindo do contraste entre as reflexións de Carvalho Calero sobre a poesía como catarse, cun forte compoñente pulsional na xénese, e o carácter marcadamente intelectualizado, arquetípico e simbólico da que el compuxo, trátase de facer un percorrido polos seus poemarios na procura dos materiais procedentes do vivencial e de analisar algunha das estratexias de "elusión" e ficcionalización do eu: as máscaras do suxeito lírico, o discurso irónico, o mito.
\end{abstract}

\begin{abstract}
Using the contrast between Carvalho Calero's reflections about poetry as a catharsis with a strong impulsive drive at its root, and the markedly intellectualised, archetypal and symbolic character of his works, this contribution aims to revisit his poetry collections by tracing the materials he took from life itself and to analyse some strategies of "evasion" and fictionalisation of the self: the masks of the lyrical subject, ironic discourse and myth.
\end{abstract}

Palabras chave: Ricardo Carvalho Calero, poesía.

Key words: Ricardo Carvalho Calero, poetry.

\section{1 .}

Ricardo Carvalho Calero, poeta. A publicación dunha escolma de poesía en 1992, pouco tempo despois da súa morte, foi unha sorpresa para moitos leitores, pois o maxisterio como historiador da literatura, crítico e lingüista e a repercusión considerábel do romance Scórpio (1987) foran embazando todo o demais. As escolmas realizadas recentemente aparecen nun contexto ben diferente: tras décadas de exclusión e silenciamento por moitos dos que nun tempo foran "paxarinhos da mesma posta" (Cantigas de amigo e outros poemas, 1986), cos mesmos ideais postos 
na "gran Galiza utópica” (Blanco 2020, p. 235), agora transformada nunha simple Galiza autonómica, a obra enteira de don Ricardo precisaba dunha redescoberta.

Vou tentar, inxenuamente, acreditar en que neste estraño 2020 ese descoñecimento foi emendado e imaxinar agora o desconcerto de quen, coñecendo algo do labor poético de Carvalho, lea por primeira vez as reflexións que sobre el fai nos libros de conversas con Miguel-Anxo Fernán-Vello e Francisco Pillado (1986), Carmen Blanco (1989) e Francisco Salinas Portugal (1991), os dous últimos oportunamente reeditados. Tamén á inversa, dada a aparente discordancia entre unha poesía mui reflexiva, intelectualizada, emocionalmente contida e até por veces distante, e a concepción carvalhiana da poesía como catarse. Con palabras sinxelas, lonxe da pedantería e dos tecnicismos, afirma:

A poesia para min non é outra cousa que catarse [...] Eu planifico escasamente o meu quefacer literário e menos a miña actividade poética. Ordinariamente fago un poema cando experimento unha vivéncia cuxa intensidade me exixe para non desacougar-me demasiado unha transformazón en comunicazón expresiva" (Fernán-Vello e Pillado 1986, pp. 148 e 230-231).

Chega mesmo a comparar a produción dun poema cun "derrame sanguíneo" no poeta "que canta aquilo que lle canta dentro dun momento determinado" (Salinas 2020, p. 97).

Un leitor non avisado quizais agarde, entón, unha poesía pulsional, en enxurrada emocional, seguramente expresión directa desas vivencias ás que Carvalho alude. Se é coñecedor da poesía española do XX, pode evocar a poesía de la experiencia; quizais siga a dos poetas youtubers, tan exitosos e con tanto volume de vendas. Poesía do eu, esta, propia dunha época de abolición das fronteiras entre o íntimo, o privado e o público e de insaciábel narcisismo. A roupaxe non acai demasiado ben a don Ricardo, sempre pudoroso, nada egótico, profundamente reflexivo e especulativo. Nin a el nin á súa poesía.

Esa vaga de poesía máis ou menos autoconfisional, por fortuna practicamente ausente entre nós, coexiste coa moda da autoficción narrativa desde hai décadas na literatura francesa, en plena eclosión na española e comezando a manifestarse na nosa.

Como se dunha novata escritora de autoficción se tratase, que narra o pretendidamente real e verdadeiro, acontecido a ela propia ou aos outros, ao tempo que tamén conta os mecanismos de construción do seu relato, revelo que a esta incursión nas "ficcións do eu" na poesía de Carvalho Calero me foron levando esas aparentes discrepancias entre as reflexións do poeta sobre a función catárquica e os textos nados dese "derrame sanguíneo" inicial; a vaga impresión dos camiños 
inversos que a moda narrativa actual en certas literaturas e a poesía levan, en canto esta, como artefacto artístico, supón sempre un proceso de distanciamento, depuración, obxectivación do que inicialmente pode ser vivencia autobiográfica ou heterobiográfica, falando en termos do mesmo Carvalho; tamén a análise de Scórpio que Darío Villanueva fai en Ricardo Carvalho Calero. As formas do compromiso, libro de homenaxe da Universidade de Santiago de Compostela, por mor deste Día das Letras a el dedicado e, finalmente, a leitura de La belleza del marido, tradución ao español do libro que Anne Carson publicara en 2002. Sei que non desagradaría a don Ricardo, confesadamente cosmopolita e universalista no diálogo con outros autores, esta conexión entre Carson e a poesía del.

En "Scórpio, autoficción contra posliteratura" (2020), Darío Villanueva analisa o tratamento do material autobiográfico no romance e no relato O lar de Clara, recollido por Carvalho na súa Narrativa completa (1984):

Hai [...] un aspecto sumamente salientábel en O lar de Clara que adianta un enfoque semellante en Scórpio. Refírome a unha sorte de pudor polo que o novelista agocha o contido autobiográfico do seu relato mediante unha habelenciosa modalización do mesmo. As técnicas son distintas, mais o propósito é o mesmo: producir unha desconexión textual entre a perspectiva do narrador e a experiencia autobiográfica do autor. En O lar de Clara, novela escrita en primeira persoa, xa no segundo capítulo se explicita, en verbas do narrador, que non é un novelista nin un intelectual, senón un home de negocios que non sabe para quen escribe nin por que o fai [...] Emporiso, do que se fala é das lembranzas infantís de Ricardo Carvalho Calero como el mesmo recoñecerá en entrevistas posteriores. $\mathrm{O}$ artificio da autobiografía como desfiguración, por dicilo nos exactos termos de Paul de Man (1979) [...] pasa neste derradeiro romance polo perspectivismo metanarrativo, de xeito que a pegada autobiográfica do personaxe que dá nome á obra se agocha trala figura dun alter ego, a figura de Salgueiro, e trala presentación calidoscópica do protagonista por parte dunha xeira cumprida de puntos de vista individuais (Villanueva 2020, pp. 155-156).

E a seguir estabelece a relación coa autoficción, neoloxismo nado no 1977 para se referir a unha tendencia que parte da fusión entre as entidades narrativas do autor concreto, o narrador e o protagonista, mais cunha "liberdade imaxinativa privativa da novela no que se refire aos acontecementos narrados e aos seus protagonistas, que son personaxes de ficción" (Villanueva 2020, p. 156).

Nin tanto, en moita da autoficción última. O elemento ficcional inherente ao xénero novelesco (por algo o termo portugués é precisamente ficção) tende a reducirse e até a desaparecer. Véxase o lanzamento da última obra de Emmanuel 
Carrère, Yoga, publicada en Franza o pasado agosto, e que viría sendo a súa "autobiografía psiquiátrica", a do autor real. Carrère ten advertido en entrevistas aos medios que neste libro "non todo é verdade", a diferenza dos seus romances anteriores. A inclusión de elementos ficticios é malevolamente atribuída por algúns a que o prestixioso Premio Goncourt só premia a ficción.

As obras carvalhianas (e talvez habería que engadir os relatos de recriación da infancia Os tumbos e As pitas baixo a chúvia, recompilados no 1982 en A gente da Barreira e outras histórias e no 1984 na Narrativa completa) seguirían entón os códigos da autoficción inicial, nun xogo complexo e requintado entre o real e o ficcional, xogo de selección estética dos materiais brutos da escrita, de depuración, ruptura de fronteiras e pacto intelixente co leitor-leitora. Nin notario de si mesmo nin notario do que acontece fóra do romancista: "mentiras verdadeiras". Como as da poesía. Di Anne Carson:

Todo mito es un patrón ornamental, una proposición de dos caras que permite al usuario decir una cosa y significar otra, llevar una doble vida. De ahí la noción primitiva en el pensamiento clásico de que todos los poetas mienten.

Y de las verdaderas mentiras de la poesía se filtró una pregunta.

¿Qué une realmente a las palabras con las cosas?

E tamén:

Los poetas (sed generosos) prefieren disimular la verdad bajo estratos de ironía porque esa es la apariencia de la verdad: en capas y elusiva.

Mentiras que revelan a verdade, verdades que se enmascaran de ficción, a complexa relación entre a palabra e a cousa, a función do mito, a verdade e a aparencia, a ironía, a reflexión metaliteraria. O xogo de complicidades co leitor nunha obra, a de Carson, que, abolindo as fronteiras entre poesía, ensaio e relato, podería levar a confundir, se ese leitor for inxenuo, as peripecias e emocións do suxeito lírico coas da propia autora, ao tempo que ese mesmo suxeito o avisa de que non se fíe. Como Pessoa, na súa tan citada "Autopsicografia":

O poeta é um fingidor.

Finge tão completamente

que chega a fingir que é dor

a dor que deveras sente. 


\section{2.}

No estudo acima citado, Darío Villanueva aponta que Carvalho está se callar a se inspirar nos versos de Pessoa á hora de xogar "creativamente coas lóxicas e desexábeis ligazóns entre vida e literatura" (Villanueva 2020, pp. 158-159). Outro tanto fai, no mesmo volume de homenaxe, Carlos Quiroga cando en "Verdadeiro poeta foi -ou a poesia é demasiado séria" vincula ao texto pessoano o poema "A maior parte desta poesia" (Reticências..., 1990) que, cuida, "empequenece a teoria do fingimento pessoano" (Quiroga 2020, p. 143):

A maior parte desta poesia

é hipocrisia.

Nom quer nada dizer e nada di.

Se algo quiger dizer, algo diria.

Quer somente fingir que nom fingia

oferecendo enganos para ti,

que finges crer que é verdade

a mensagem que te envia,

e finges que tés saudade

da saudade que exprimia

alguém que nom a sentia,

mas que se enganava assi,

cúmplice da tua porfia

de enganar a ti e a si.

A ti fingindo entender.

A si fingindo saber

o que queria dizer,

ainda que nom o sabes;

pretendendo ter as chaves

para abrir

o que nunca se fechou,

porque nunca tivo portas,

e aquelas palavras mortas

ajuntavam-se ao achou,

nom por santa inspiraçom,

nem por subconsciente graça:

por rotineira trapaça

e vazia pretensom. 
Assi, é feita desta arte, com notória hipocrisia, a maior parte

desta poesia.

(Carvalho 1990, pp. 122-123)

Non hai no texto, ao meu ver, autoanálise ou revisión crítica da poesía propia e do que nela puder haber de "notória hipocrisia"; si unha valoración das eivas que observa en parte da poesía galega na altura en que Salinas o entrevista, 1989:

Falta de sinceridade, un desexo de barroquismo a toda custa, unha procura da escuridade e do hermetismo que non está fundada na complexidade do pensamento lírico, senón que responde a unha moda semellante á moda que facía -pouco tempo hai- utilizar exclusivamente temas políticos ou sociais para a poesía(Salinas 2020, p. 99).

Nin "palavras mortas", filigrana de estilo de quen nada ten que dicer, nin reflexo directo das vivencias, sexan estas individuais ou colectivas. Véxase o poema 22 de "Excalibur" (Futuro condicional, 1982), aínda que nel non se refira especificamente ao labor poético, senón á maneira de se enfrontar á vida en xeral:

Todo o apontas, todo o anotas,

todo o lembras;

implacábel notário

da vida en bruto, bruta.

(1982, p. 45)

E advirte:

Mais un pazo, unha igreja, unha casa non son só materiais.

Tes que poñer a forma

luindo, rejeitando, escolmando.

A verdade non é todo, a verdade

é a eséncia da existéncia, non a existéncia en bloque. Non toda a vida é vida. 
Tan verdadeiro es

que registas as mesmas mentiras.

Vou facer-che un regalo: unha peneira

que non deixe pasar

o farelo da vida.

Non te asañes, non digas

que é unha peneira mintireira.

É de fariña munda, sen farelo,

o verdadeiro pan.

(1982, p. 45)

Máis adiante, no poema 30 da mesma sección avisa:

Toda a verdade é demasiado feia.

Toda a beleza é demasiado falsa.

$[\ldots]$

Toda a verdade é demasiado falsa.

Toda a beleza é demasiado feia.

(1982, p. 53)

Tamén en Conversas en Compostela con Carballo Calero, e a propósito d'O siléncio ajoellado, insiste na subtil relación entre o material bruto da escrita procedente do real e a súa transformación, seleccionando e obxectivando, na construción literaria:

Creio que a miña poesia [...] sempre ten unha referéncia a un mundo real, e non se pode prescindir desta referéncia, ainda que pode ser logarítmica e, se cadra, este é o camiño real da poesia, porque unha poesia puramente fotográfica é tan inane posivelmente como a pintura propriamente realista que non aspira mais que a reproduzir con exactitude a realidade [...] Entón, a poesia, como a arte en xeral, ten que ser unha cousa distinta da acta notarial, mediante os procedimentos técnicos que sexa, da realidade tal como a percebemos nós (Fernán-Vello e Pillado 1986, p. 90).

En Voz e silencio supón que a súa poesía xamais ha chegar a ser propiamente popular, mais admite que "non deixou de ter algunha influencia nalgúns máis mozos, que máis ou menos espontaneamente foron sensíbeis a esa autenticidade que é o único mérito da miña poesía, se é que ten algún mérito" (Salinas 2020, p. 98). 
Velaquí, pois, a fórmula secreta. Ese fráxil equilibrio entre a experiencia e o labor de depuración estética do que, procedendo do real, sexa individual ou colectivo, sexa vivido ou soñado (e estamos perante un dos grandes conflitos carvalhianos, a relación entre vida e soño, a intuición de que o soñado é a vida verdadeira), vai sendo espido do particular, transitorio e continxente até acadar unha dimensión arquetípica e achegarse á verdade. Por moito que Carvalho ande sempre a perguntar que é, no fin de contas, a verdade e chegue mesmo a negar que o interese do poeta sexa propiamente ela. Así en Anjo de terra (1950):

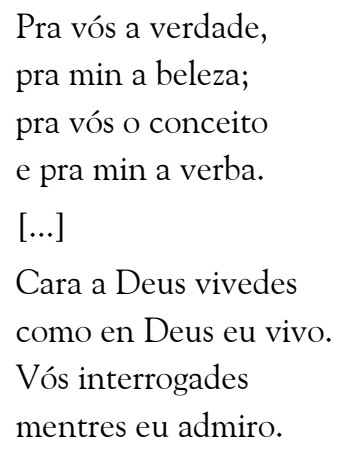

(1980, p. 110)

E é que o "verdadeiro poeta" non é o que anda ás voltas coa verdade, pois toda verdade é relativa e múltipla, unha cuestión de perspectiva, senón o que se entrega ao labor poético cunha autenticidade moitas veces incompatíbel con modas e conveniencias, como o do texto de Reticências..., que é posíbel ler como autorretrato:

\author{
Verdadeiro poeta foi. Nom escreveu \\ para os poetas. Cantou \\ para os homes. Aqueles, \\ monstruosamente desumanos, \\ nom o admitirom nos seus coros, \\ porque desentoava \\ a sua clara voz \\ da balbúrdia a maotenta \\ que eles obscuramente articulavam. \\ A poesia é demasiado séria \\ para que se administre \\ tecnocraticamente. \\ Mas eles nom pensavam assi. Criam \\ num corporativismo autoritário.
}


Quanto aos homes, nom lêem

as revistas, os livros de poesia.

Mas ouvirom alguns

aquela voz, e crerom

que era a sua própria:

assi que lhe prestarom atençom,

porque nada interessa tanto a um

como um mesmo. E ficarom admirados

do bem que se exprimiam.

Este foi o destino do poeta

verdadeiro. Os seus colegas

o seu nome apagarom

no escalafom que editam

profissionalmente. El nom estava sindicado.

Os homes que o escuitarom

e crerom escuitar-se,

tamém nom conhecerom o seu nome,

naturalmente, o nome del.

Excomungado, anónimo,

viveu, morreu. Já somente eu o lembro.

Poeta verdadeiro.

(1990, p. 52-53)

\section{3.}

"Eu estou educado segundo uns princípios que repugnan a complacéncia no autorretrato", advirte Carvalho no limiar a Pretérito imperfeito (1980, p. 9), volume que recompila e selecciona os poemarios publicados até o 1961. E cando dous anos despois recolle poemas inéditos ou antes dados a coñecer en publicacións periódicas en Futuro condicional (1961-1980) explicita o criterio seguido: "O autor procurou que o número de poemas deste segundo tomo coincidise co do tomo primeiro, e eliminou o material excedente, que lle pareceu de calidade inferior ao conservado, ou expresión pouco comunicativa de vivéncias demasiado persoais" (1982, p. 9).

Non sería difícil, con todo, deseñarmos un retrato interior de Carvalho Calero, un dos poetas que con máis autenticidade, condición sine qua nom para el da verdadeira poesía, ten exposto na obra de criación a súa visión da existencia. Interrogación sobre o sentido desta, procura dunha transcendencia albiscada e 
negada, escepticismo, relativismo e pluriperspectivismo, a conquista final dunha certa conformidade. Nas Conversas en Compostela afirma:

Os homes que nasceron polos anos que eu nascin e se educaron e se formaron culturalmente polos anos en que eu me formei, temos -se hemos crer a Spengler- unha conciéncia fáustica do mundo, en canto somos criaturas da cultura occidental. E esa sede de infinito, esa arela de ir sempre mais alá que caracteriza o home fáustico marca-nos a todos (Fernán-Vello e Pillado 1986, p. 148).

Afirma nas Conversas en Compostela. Ese é seguramente o eixo da súa posición vital e da súa obra poética. Expúxoo mui fermosamente en "A Álvaro Cunqueiro, 1980" (Futuro condicional), poema composto o ano en que recebeu a Cunqueiro como doutor honoris causa na Universidade de Santiago de Compostela. Fillos os dous, nados no 1910, do século XX, afástaos a maneira tan diferente en que un e outro encaran a vida e os límites da humanidade:
Ai, Álvaro Cunqueiro: ti, fillo de Lilith, primeiro amor de Adán, non sujeita ao pecado, vas escrebendo a crónica dos dias anteriores à serpente e à árbore, cando eran inocentes o bico e o belisco e aniñaban nas nubes as sereias e os anjos. Os tristes fillos de Eva mordemos as mazás que se desfán en cinza. Ainda nados polos mesmos anos, amargurou a nosa vida o zumo do admitido e do vedado.

(1982, p. 219)

Mui similar é a caracterización de Cunqueiro e de si propio en "Para o doutor Cunqueiro", evocación do amigo morto publicada en Grial en 1981. A recriación do paraíso cunqueiriano, anterior á caída e á culpa, lizgairo e sensual, é mui frecuente en Futuro condicional e aparece tamén nos últimos poemarios de Carvalho, sempre ligado aos soños de harmonía e de reconciliación coa vida por parte dos torturados "fillos de Eva" entre os que don Ricardo se inclui. 


\section{1.}

Menos evidente é a presenza de elementos autobiográficos, correspondan á historia individual ou á colectiva, tan determinante esta para quen sempre se recoñeceu membro dunha xeración, a do Seminario de Estudos Galegos, que el denominou tamén "Xeración Halley". Mais, oculta entre metáforas vangardistas, saudade do Absoluto, absurdo existencial, reflexións sobre o amor, indagacións no misterio da feminidade e reelaboracións de mitos esenciais da nosa cultura, está a experiencia vital do autor. A dos anos ferroláns (tan marcados pola morte da nai a causa da denominada gripe española na segunda vaga de 1919, e polas da tía/ madrasta e dous dos seus irmáns), recríase libremente n'O lar de Clara, como xa se indicou, mais figura tamén nun número importante de poemas de diferentes épocas, aínda que eludindo detalles particulares e fuxindo do puramente confisional. Salienta entre todos "Evocazón da infáncia perdida" (Vieiros, 1931). "Eu, neno, matei a miña infáncia / co coitelo da miña gravidade", confesa o suxeito lírico. Segundo Aurora Marco, nel "achamos referéncias que se poden considerar autobiográficas. A alusión á gravidade daquel neno, tan marcado pola disgrácia familiar, é corroborada por quen o coñeceu e tratou cando veu a Santiago, sendo aínda mui novo" (Marco 1992, pp. 22-23).

Destaquemos tamén "E a roda vai girando, como a do afiador" e "E calquei a soleira bretemosa" (Saltério de Fingoi, 1961). A ausencia da nai evócase no primeiro, aínda que en lugar dun eu hai un nós e o biográfico é ponto de partida para a reflexión sobre unha saudade metafísica:

\footnotetext{
Mais cintilas abrollan. Alguén abre a fiestra, alguén acende a luz na estáncia dos cativos. Un despertar, un esfregar os ollos, unhas salgadas bágoas, uns beiciños, un berrar pola nai. Mais despertos ficamos. E recibir podemos a presenza paterna que ven a nos dicer: ergue-te e vai à escola. Se non adeprendéramos o duro silabário, nunca ler poderíamos no libro das estrelas.
} (1980, p. 139)

En "E calquei a soleira bretemosa" unha "femínea sombra" recebe o poeta no Alén: 
Semellaba-me. iDeus! Vin-me a min nela.

Pero era máis nova ca min. Por ve-la acaroei-me. ¿O teu nome? E alguén: di-llo.

$\mathrm{Na}$ terra foron os meus anos menos

-falou-, mais vin primeira os teus acenos.

Dixen eu entón: nai. Dixo ela: fillo.

(1980, p. 195)

A Futuro condicional pertence "Ferrol, 1916", con moitos elementos comúns a O lar de Clara na evocación da casa familiar, dos seres queridos e das rúas ateigadas "de pregóns de sardiñas / e de ingleses que vendian Bíblias":

Eu tiña un pacto con Deus:

que ninguén dos meus morreria.

E o pacto era observado,

e eu confiaba na perenidade do pacto.

Todo isto fica tan longe

que aduro podo ainda lembrá-lo.

Esqueceria-o dentro de pouco tempo

se non escrebese estes versos.

(1982, p. 172)

É posibelmente a mesma cidade á que regresa, xa vello, para dar coa ausencia daqueles a quen amou e aos que confía achar de novo sen moita demora:

Vinhem aqui para os visitar,

e nom os achei.

Foram-se.

Caminho errante e só polas ruas

onde pensava abraçá-los.

Eles já nom estám aqui.

Estám juntos noutro lugar.

E eu estou só neste lugar.

$\mathrm{Na}$ cidade onde todos nacêmos.

(1990, p. 19)

A cidade na que noutro poema do mesmo libro, Reticências..., se dispón a entrar un suxeito lírico agora totalmente identificábel co autor real, se ben o 
biográfico-anecdótico é de novo pretexto para a reflexión de signo metafísico sobre o ser humano uno e múltiplo:

De um jeito ou outro,

hei de entrar no meu povo,

para ver se tropeço

numha rua qualquer do Ferrol Vello

-será a de Sam Francisco, a do Socorro?-

com o neno que fum e que foi outro;

aquel que fum e que nom fum entom,

quando eu nom era o velho que hoje som.

(1990, p. 67)

\section{2.}

Hei de recoñecer que en todas as miñas leituras anteriores me pasara case desapercibida a presenza do vivencial na poesía de Carvalho. Obxectivo cumprido pola súa parte, xa que acho que son propositados e mui meditados os recursos empregados para velar o eu e as súas vicisitudes. Ás composicións de raíz autobiográfica cuido que lles poden ser aplicadas as matizacións do autor a respeito dos temas políticos presentes en "Avalon", a terceira sección de Futuro condicional, e en "Arredor de si" e "Ilha de luz", ambas pertencentes a Reticências...:

Hai moitos destes poemas que son de tema político, pero non son poemas políticos. A realidade política que serve de base ao poema está enfocada como realidade humana; non son poemas comprometidos cunha determinada dirección ideolóxica, aínda que pode ser que nalgúns deles estea presente unha determinada ideoloxía, xa que non podemos facilmente prescindir dos nosos puntos de vista cando enfocamos as realidades sociais. Pero, en xeral, o que se revela nestes poemas é o que de interesante humanamente hai nos feitos políticos. (Blanco 2020, pp. 227-228).

O que de interesante humanamente hai nos feitos acontecidos ao autor real, poderiamos engadir nós. E é que hai coherencia absoluta entre os principios éticos e o pensamento filosófico de Carvalho e as súas realizacións poéticas.

Releo agora e resúltame especialmente dramático e doloroso o contraste entre o entusiasmo dos poemas que en Vieiros (1931) e n'O siléncio ajeolhado (1934) evocan os anos xuvenís de don Ricardo na Compostela universitaria, cando el era xa poeta destacado e militante nacionalista radicalmente comprometido, e a 
amargura dunha peripecia persoal inserida na gran traxedia colectiva da guerra civil e a ditadura. Subxace á procura angustiada dun sentido en textos de Anjo de terra (1950) e de Poemas pendurados dun cabelo (1952) e cobra protagonismo no poemario máis desolado, Saltério de Fingoi (1961).

Á par de poemas na esteira dun Modernismo tópico (e mui anacrónico, como ten recoñecido don Ricardo) e doutros que sorprendentemente apontan xa temas e conflitos basilares na súa obra (véxanse "Filosofía", "Abisag", "Evocazón da infáncia perdida" en Vieiros e "O sexo do anjo" n'O siléncio ajoelhado), salientan os que, cos xogos metafóricos, o ludismo e a presenza constante dunha natureza animizada comúns a moitos poetas practicantes da vangarda racional (criacionista, cubista, hilozoísta ou ultraísta), recrían a vida universitaria, o primeiro grande amor, a camaradaxe, a dedicación xuvenil á poesía. "O estudante adoecido" de Vieiros identifícase co xílgaro engaiolado en tanto convalece e imaxina os claustros e aulas universitarias dos que provisionalmente está ausente. É o mesmo suxeito que en "A miña estilográfica" encadea ousadas imaxes vangardistas, lizgairas e intranscendentes, en homenaxe ao humilde obxecto:

Meu segredario para

escribir cartas á noiva

$[\ldots]$

e tomar apuntes das conferenzas

de cátedra.

(1931, pp. 51-52)

Foguetes verbais como en "Bibliófilo" ou como nun "Noiturno compostelán" que finda cuns versos case excepcionais na poesía carvalhiana da época, practicamente a única referencia ao nacionalismo no que o autor real militaba:

A praza da Quintana, baixo o luar, soñaba n-un rexurdir grorioso da Galiza.

(1931, p. 46)

Mención especial merecen os poemas amorosos que, lonxe xa da delicuescencia dos tópicos romántico-modernistas, falan dun amor mui real e mui concreto. A imaxe de María Ignacia, a xoven e brillante estudante luguesa que ha ser compañeira de vida, intuise na "nena inxele" que en dous poemas neotrovadorescos, con paralelismo e leixa-pren mais cun suxeito masculino, "vive nunha cidade de montana” (“Ai, Deus, qué lonxe está de min!”); na amada da que "O estudante 
adoecido" ten saudades; na estampa luguesa de "Parque", todos poemas de Vieiros. En O siléncio ajoelhado impón a súa presenza en "Teu retrato diante de min", en contraste coa fascinación un tanto inocente provocada pola beleza feminina en "A Maruxa Abad, pol-os seus bucles mortos" e "Luísa Sorriso". O retrato da rapaza amada, protexido por un cristal que reflicte as feizóns do namorado, ten capacidades case premonitorias:

Dubidoso espello anticípa-me paternidades.

[...]

a faciana que terá

o fillo noso que durme

la, no berce do vindeiro.

(1934, p. 63)

O poema final de Anjo de terra (1950), "Os vellos amigos" alude á "roda dos dias escolares, / tan doada de apurrar", que bota a xirar na lembranza cando "os vellos amigos" fan presentación das "suas mulleres novas":

O mundo era pra nós un gran de anis, atlantes de vizosos lombos.

A brillante cometa da lembranza cintila.

A sua cabeleira é como a desta moza que nos sorri.

Ja virá logo a cola da saudade.

(1980, p. 113)

\section{3.}

É sabido que don Ricardo non gostaba de falar da guerra civil e que só na vellice se enfrontou literariamente a ela, de maneira directa en Scórpio (1987) e tomándoa como base, desfigurando subtilmente as circunstancias reais para unha reflexión sobre o poder, na peza teatral Os xefes, datada no ano 1980 e publicada no Teatro completo dous anos máis tarde. Os poemas sobre ela son, pois, contados: "Viage" e "Ese neno" en Saltério de Fingoi, "Non sei / se matei" en Futuro condicional. Neste e no primeiro pártese de situacións experimentadas polo oficial da República Ricardo Carvalho Calero, con omisión de detalles e carácter reflexivo en "Viage" e na abolición de fronteiras entre o autobiográfico e o literario no texto de Futuro. 
"Ese neno" elude o persoal e precisa da complicidade do leitor. Unha estampa de guerra (inominada): a do neno morto no colo da nai ao pé dunha boca de metro. Son quizais a nai e o neno do Guernica, protagonistas tamén dun magnífico relato de Lueiro Rei en O sol na crista do galo (1982); ou tamén a nai que foxe cara a un arrabalde pimenteliano, cunha "túnica branca, un manto azul" que a han ir vestindo até a converter nunha nova Piedade:

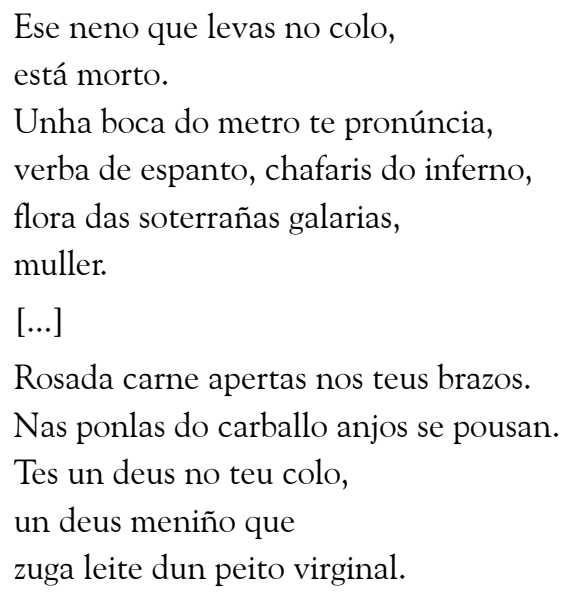

(1980, pp. 207-208)

\section{4 .}

Moito máis abundantes son os poemas nos que se alude, ás veces de maneira oblicua, suxerindo e velando, ao exilio interior padecido polos vencidos da guerra. En Poemas pendurados dun cabelo (1952) talvez sexa o que se oculta tras o xogo alegórico e simbólico de "Etzelnburg" e de "Rillaba a mágoa o seu corazón forte". Un novo Etzel (Atila), unha mágoa que pode non ser precisamente metafísica.

É sen dúbida Saltério de Fingoi (1961) onde a amargura deses anos agroma con intensidade entre a reflexión de carácter existencial, ou mesmo especificamente existencialista, e o achegamento ao mito como vía para achar refuxio e sentido. A catástrofe arquetípica é tamén a catástrofe da guerra en "Oh néboa, oh néboa", coas referencias a Zeus e un final no que "unha luz peneirada enmolece os ríspetos despoxos", nunha estampa de destrución similar á de "Etzelnburg" (Carvalho ten, por certo, advertido que hai textos de Saltério contemporáneos dos de Anjo de terra e Poemas pendurados dun cabelo). En "Intre de soledade no campo" o suxeito lírico, cun ti autorreflexivo, refúxiase "so coa terra, na terra, dentro dela, / como nun berce, ou ventre da sua nai" para sobreviver á hostilidade social: 
Foron-se os inimigos.

Deitaron-se os servos que te ódian.

Afastaron-se os amos que te esculcan.

[...]

E, esquecendo a tua vida,

pos a testa no colo da tua nai;

(1980, p. 144)

Hai moitos máis poemas a ter en conta: "iE de verdade foi? ¿Foi de verdade?", "Non sei. ¿Dormir? As tempas tristes, cándidas", "Esquezo", "Ollas, meu ben, as cañas dos Ancares", "Esta nada que che traio". O eu enmascárase adoito cun ti autorreflexivo, un nós arquetípico, a imaxe do carballo no que aniña "a saudade cantora" (a dun pasado coas arelas de futuro que o sostiñan, esa mistura de lembranza e desexo que imposibilita o presente):

Non sei se foi verdade;

pro devén máis vizosa e máis garnida

-edra ao tronco cinguida-

que a árbore da cal foi ornamento,

falsa quizá, mais verdadeira vida.

(1980, p. 176)

Angustia e exclusión son vividas en compañía. De novo, aínda que non se nomee, Maria Ignacia. Ela ha ser a raíña á que o suxeito lírico só pode oferecer como galano a desolación e a constatación da nada; ela é, agora de forma transparente, o ti ao que un suxeito fusionado co autor real se dirixe en "Ollas, meu ben, as cañas dos Ancares", un dos raros poemas onde se concretan topónimos e circunstancias vitais:

Bate o nordés Fingoi. Acobillada

à lapa do fogar tabula a nena.

Non coides, porque a mágoa onte se fose, que hoje non veña.

(1980, p. 177)

E, finalmente, tras dous poemarios nos que este tema está ausente, "Como pudemos?", o texto de Reticências... que moitos consideramos un dos poemas 
maiores da nosa literatura e o que máis lucidamente mostra o drama dos que tiveron que viver cos "olhos múltiplos e insones/ de Medusa fixos em nós à espreita":

\author{
Muitos morrerom, mas \\ nom falo agora desses mortos; falo \\ dos que tiverom que viver morrendo \\ entre os seus matadores, lendo a imprensa \\ que de lama os enchera, saudando \\ as insígnias contra as quais militaram. \\ Como pudemos \\ viver? E mais vivêmos. \\ E comêmos, dormímos, engendrámos \\ crianças: se havia quê comer, se havia \\ leito para dormir ou para amar.
}

(1990, pp. 129-130)

\title{
3.5 .
}

Posibelmente as vivencias persoais de Carvalho máis presentes nos seus poemarios son a exclusión por parte do que el denominou holding e a experiencia da vellice e a proximidade da morte. Resulta curioso constatar que o persoal vai cobrando protagonismo a partir de Futuro condicional simultaneamente a un interese cada vez maior polos temas de carácter histórico e político, dos que xa temos anotado a presenza en seccións de Futuro e de Reticências... Carvalho como "poeta total", tal como el se recoñecía, na esteira do seu admirado Cabanillas, alleo á poesía de especialista, atento ás múltiples angueiras humanas (Salinas 2020, p. 97).

Hai xa un adianto da súa confrontación co holding na sección "Excalibur" de Futuro condicional. Nela salienta o carácter confisional se o compararmos coas obras anteriores, cun eu como suxeito dominante mais evitando nomes e detalles e recorrendo ao alegórico-simbólico, que calla en poemas magníficos como "Non me pidades que acade aquela harpa", "Un fungueiro na man direita", "Pola fiteira do meu castelo sitiado" ou "Cidade dos homes. Ao serán". Bota tamén man da ironía, procedimento para distender a negrura dunha sección que ten como eixo a renuncia, o contemptus mundi, a asunción dunha soidade metafísica e social. No poema 9 o suxeito vese como "un débil home só,/ neste país tan abundante en deuses", "humilde reptil, áptero" entre "esta fauna alada/ de olímpicas presenzas". Non, xa non é o "anxo de terra" exiliado do Absoluto quen fala, senón un ser humano nun país concreto vs. unha "fauna" que tamén parece mui concreta. Talvez de aí o irónico final: 
É, verdadeiramente,

incómodo dabondo,

sendo un cativo arume.

que o vento me trouxese

a estes altos terrazos.

(1982, p. 27)

O poema seguinte, que comeza "Retiro-me, vou-me, / sen dar un portazo, / sen insultar-vos" apoia esta leitura. Nel advirte:

Considerando-me inferior a muitos indivíduos, estimo-me superior a muitas congregacións.

(1982, p. 28)

Mais a partir do poema 14 o suxeito adoita ser un nós arquetípico, "fillo de Eva" ao cabo, en textos que lembran nuns casos os de Anjo de terra e Poemas pendurados dun cabelo e noutros os de Saltério de Fingoi. Así o poema 17, onde o "invisíbel paxaro que voa" é mensaxeiro dun Alén que se nos nega e a vida unha peza de monifates que ignoran que man os move. Como no 33, "Os monifates ignoran / o argumento da farsa”.

A exclusión do autor quizais subxaza na reflexión sobre a futilidade do poder e a renuncia a el en "Elegia veneciana" e "Auletés", ambos de "Avalon". E é desde logo o tema dos poemas 4 ("Criamo-nos juntos, e parecia que éramos / paxarinhos da mesma posta"), 5 ("E agora tenho a mesma idade") e 8 ("Da montanha em que fago o meu jejum") da sección VII de Cantigas de amigo e outros poemas (1986), e do 1 ("Minha querida mai, mui mal me tratas") e o 2 ("Todos os meus filhos tenhem o cabelo branco") do apartado "Arredor de si" de Reticências... (1990).

Mui elegantemente, Carvalho elude o circunstancial e, renunciando a ser notario da realidade, deita o farelo e tece os textos con procedimentos oblicuos: as metáforas naturais sobre roladas e paxariños en soidade, episodios bíblicos, a alegoría de nais inxustas e fillos usurpadores. Tamén o diálogo intertextual con Cavafis nun poema subtil e desolado:

E agora tenho a mesma idade

que Galba cando se alçou contra Nerom, como Caváfis lembra no seu poema.

Hai vários Nerons que seria justo derrubar, mais ainda que som igual a Galba em idade nom o som em legions baixo o meu mando. 
Estes novos Nerons podem dormir tranquilos.

Setenta e três anos nom significam o mesmo

que setenta e três milheiros de lanças.

(1986, p. 157)

\section{6.}

Case a esa mesma década de idade, os setenta, corresponde "A Álvaro Cunqueiro, 1980", poema de Futuro condicional xa citado. Fala sen veladuras o autor real, ese Ricardo que experimentou á par que o amigo Álvaro, as mudanzas do século XX e imaxina morreren os tres a un tempo.

A morte, o esgotamento corporal, a doenza. Aparecen no poema "Ambulatório" de Cantigas de amigo e outros poemas e son o tema de moitos textos das seccións "Névoa de sol" e "Ponte de ar" de Reticências...: os número 15, 16, 21, 26, 33, 36 da primeira; os número 11, 13, 14, 15 da segunda. Tamén o poema 8 de "As pétalas da rosa", sobre o "erotismo da decadência". Os textos transitan do claramente autobiográfico ("Ás sete da manhá soa um timbre no sanatório") ao que aparenta selo para introducir un eu ficticio ("Um bom dia a velhice entrou na minha casa", "Como amei tam desenfreadamente", "E agora som um velho patrom") e da inclusión de elementos da cotiandade, mesmo vulgares, ao diálogo con En attendant Godot ("Aqui mes tés, querida") e a reflexión, tan cara a Carvalho, sobre o eu uno e múltiplo ("Quantos antroidos"):

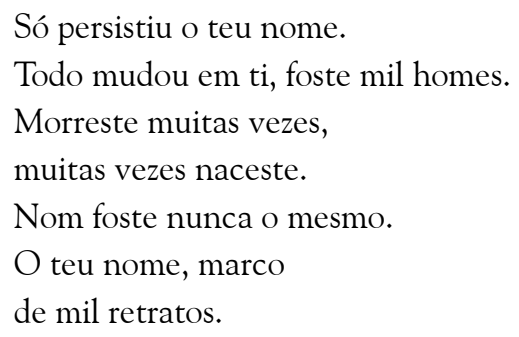

(1990, p. 50)

\section{4.}

"Marco de mil retratos": o do cativo serio e precoz; o do mozo universitario, poeta e militante idealista dunha "grande Galiza utópica"; o do oficial defensor da República; o do "que non morreu" e sobrevive baixo a ollada desapiadada de Medusa; o marxinado polos que antes foron compañeiros; o vello ante a doenza e a morte.

Todos eses retratos están na súa obra poética, aínda que case nunca dunha maneira evidente, como fomos vendo, pois Carvalho rexeita o particular e 
subxectivo e toma o real como apoiatura para unha indagación que quere ser arquetípica e o eu como manifestación concreta do humano. Algo así teríamos que intuír só con ler o seu primeiro poemario, Vieiros. En "Evocazón da infáncia perdida" a omisión dos dramas causantes da súa gravidade, aqueles que o ateigan "cedo da ciéncia da dor", deriva na intelectualización da experiencia e adianta o conflito vida-pensamento, o do ser humano fáustico occidental.

Mui significativa da concepción poética de Carvalho é tamén "Abisag", unha das súas primeiras aproximacións ao mito. $\mathrm{O}$ interese poético polas relacións Vello-Moza e a presenza deste tema nos estudos carvalhianos sobre Os vellos non deben de namorarse e no fermosísimo e irónico relato de 1979 Aos amores seródios teñen levado algúns leitores a supoñer unha relación entre o literario e posíbeis experiencias, vividas ou soñadas, do autor real. "Abisag", o poema dun poeta ben novo, destrui a leitura biografista e revela que a relación Vello-Moza é para Carvalho manifestación da traxedia do ser humano en loita, de antemán fracasada, contra a morte.

Reparemos aínda no "Retrato de poeta" que abre Anjo de terra. Carvalho ten sinalado que o poeta retratado é efectivamente el, mais nun complexo proceso de distanciamento case autocaricaturesco, pois non se retrata a si propio simulando que retrata a outro, senón ao poeta Carvalho retratado pictoricamente por Tomás Barros (Blanco 2020, pp. 233-234). Un eu duplamente ficticio para revelar, ao cabo, o eu verdadeiro. $O$ poeta fingidor.

\section{1.}

Todo mito é "unha proposición de dúas caras [...] que permite ao usuario dicer unha cousa e a contraria, levar unha dobre vida", afírmase no poema de Anne Carson acima citado. Mente, pois, o mito? En "dicer unha cousa e a contraria" consiste tamén a ironía, que vén sendo a antítese da hipocrisía en canto esta finxe a verdade para mentir e aquela di aparentemente a mentira para revelar a verdade, tal como Wladimir Jankelevitch sinala en L'Ironie (1964), que citaremos na tradución española. Moitos dos trazos e funcións da ironía por el sinalados son totalmente atribuíbeis á poesía de Carvalho: a consciencia como xerme da ironía, o pluriperspectivismo como consecuencia da ollada irónica sobre o mundo, a ironía como actitude antipatética e antienfática ("Pola graza da ironía, o pesado transfórmase en leve e o leve en ridiculamente grave", Jankelevitch 1982, p 71), a reticencia como vehículo da ironía e xogo de complicidades co receptor no paso do explícito ao tácito. Especialmente acaídas son as reflexións sobre as similitudes entre os mecanismos da ironía e os da linguaxe, "unha especie de tradución mui libre (do pensamento) que, porén, chega a expresar bastante ben o sentido xeral" (Jankelevitch 1982, p.41). Hai bastantes textos carvalhianos que xiran ao redor 
da relación entre a palabra e a cousa, con perspectivas por veces contraditorias. Así, en Reticências... a palabra é unhas veces sagrada ("As palavras nom podem profanar-se. É o logos / quem configura o cosmos") e outras armadura oca, a vestir realidades e valores xa hai moito extintos, "espectros sem sentido", como tan lucidamente se indica en "No Líbano non hai cedros do Líbano".

Falamos da ironía como aparente mentira que ten como función mostrar a verdade, como "ficción do eu" a pór máscaras que simulan ocultar para revelar. Asoma (tras o ludismo inocente dos poemas de vangarda, coas súas notas humorísticas e un tanto iconoclastas, e tras a procura angustiada dos libros de posguerra) no poema 9 de "Excalibur" (Futuro condicional), xa citado, e maniféstase como actitude básica do eu en textos de Reticências... ("Douscentos mil quilómetros afastam-te de Vénus", "Alopecia em progressom socrática") e, antes, en "Umha mensagem da Dogaresa" (Cantigas de amigo e outros poemas). Neste, un suxeito en primeira persoa comeza comunicando un feito que nos sitúa no pasado de esplendor da Serenissima. Mais, sen transición, quebrando as nosas expectativas, distánciase ironicamente, revelando non ser senón máscara do autor. Non é un personaxe veneciano quen fala; é o propio poeta, e o motivo do poema non deixa de ser anecdótico e irrelevante (o telefonema dunha muller):

Umha mensagem da Dogaresa.

Permanecede tranquilos.

Nom som um poeta modernista

nem dannunziano.

Eleanora Duse nom recitará sensuais hendecassílabos com lábios morosos.

(1986, p. 125)

Mais, acaso non mitifica calquer amante o obxecto amoroso cando comeza a amar? Ou cando o amor fica no territorio do soñado, único paraíso posíbel para os máis dos humanos...

\section{2 .}

E é asi como a ironía do poema no que unha muller real se transforma en Dogaresa nos achega a outras dúas constantes carvalhianas: a exaltación do feminino e o mito. Son mui numerosos os textos en que voces masculinas que doadamente deixan adiviñar a do poeta mostran a fascinación pola muller. Mulleres múltiplas como manifestación da Muller, "Vénus de contido variábel" (Futuro condicional), 
capaces de conciliaren o divino e o humano, domeadoras do cabalo do ser. Mulleres-anxo non, mulleres-anxa:

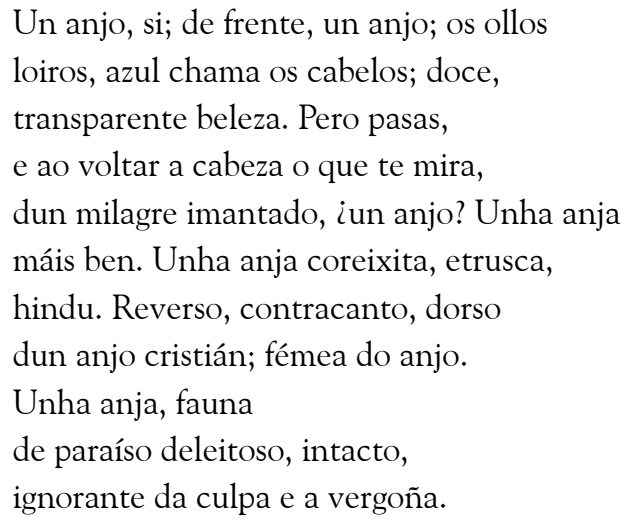

(1982, p. 127)

En Cantigas de amigo e outros poemas, como era de esperar polo título, son mulleres as que falan nas tres primeiras seccións; en Reticências... fano na que leva por título "Cantigas de muller".

Quizais o leitor supoña que se trata de confrontar a visión masculina da muller e a que esta(s) ten (teñen) sobre si. A sorpresa é que o reverso reproduce o anverso. As voces femininas son "ficcións do eu". Vense a si mesmas como as ven os suxeitos masculinos tras os que se agocha o poeta. E, como el cando as pensa, centran a súa existencia no amor, debátense entre romper a norma ou limitárense a soñar que a rompen, vacilan entre o fulgor do amor-paixón e un amor-ágape quizais máis conveniente e rendíbel.

Os suxeitos femininos son case sempre mulleres do común (a burguesa vilega, a estudante universitaria, a agregada de instituto...), mais na sección III das Cantigas de amigo e outros poemas achamos a María Mancini, Constanza Mozart, a mistress Strauss viaxeira do Titanic, Isolda a das brancas mans e a doncela Brangel, mulleres procedentes da historia ou do mito. A perspectiva que cada unha delas adopta, ben a respeito do poder, ben a respeito do amor cortés como paixón allea á vontade humana, supón en cada caso unha revisión da convención. No fundo, tamén Carvalho fala a través delas: tamén el recea ás veces do amor que é dor e morte, tamén rexeita el as miraxes do poder. 


\title{
4.3 .
}

Os personaxes míticos procedentes da materia artúrica en xeral ou especificamente da historia de Tristán e Isolda son abundantes na obra poética de Carvalho, sobre todo na sección "Avalon" de Futuro condicional e nos dous últimos libros, aínda que xa en Saltério de Fingoi figura un poema titulado "Graal". Conviven cos das mitoloxías grecolatina e xermánica e cos bíblicos. En ocasións, tal como sinalamos para os femininos, son eles o suxeito lírico: Belkis, un moderno Anquises, o Ulises que evoca o encontro con Nausícaa, un irónico Tristán, en Futuro condicional. Este último é tamén o suxeito de "Eu conduzim até o rei Marco" e "Vem-te comigo ao bosque de Morois" (Cantigas de amigo e outros poemas) e convive cun Aquiles que soña co amor-morte de Pentesilea.

O bosque de Morois transfigúrase en paraíso cunqueiriano, con Tristán e Isolda como un Adán e Eva de antes do pecado orixinal, "limpos [...], num Edém onde o amor é eterno e santo"; Venus, encarnada en muller, entra no despacho dun Anquises contemporáneo para deixar "un sabor de imortalidade" en beizos e brazos "destinados a tornar-se po"; Belkis evoca a raíña de Saba e Aquiles fantasía co regreso da amazona Pentesilea e a súa dádiva de morte e amor. As dúas posúen as feizóns da femme fatale: beleza e crueldade, arbitrariedade, sensualidade, poder. Como a "Hatseput" que abre a sección V das Cantigas de amigo e outros poemas:

\author{
Poderosa força motriz, \\ cujo motor na matriz runge, \\ vingança de mil faraónicos \\ séculos masculinos, nai \\ fecunda ou estéril, abelha \\ rainha, soberba da feminidade \\ débil, que triunfa da forte \\ virilidade, Eva \\ coroada do klaft e o ureus, \\ de torres e raios, sentada \\ en sólio de pedra, esfinge \\ que tem entre as poutas o cráneo \\ de Adám, hierofántica, amazónica, \\ Semíramis, Pentesileia, \\ Golda Meir, Indira Gandhi, \\ Margaret Thatcher, Hatseput.
} (1986, p. 102) 
A forma en que o suxeito lírico se desliza das mulleres míticas ás históricas lembra a de Carvalho pasando na sección "Avalon" (Futuro condicional) e nas dúas últimas de Reticências... dos asuntos míticos aos políticos e históricos. Non hai distancia en "Hatseput" entre a perspectiva do suxeito lírico e a do autor real. E como coincide coa de Belkis e Aquiles, non ha ser equivocado concluír que estes dous, como Tristám e Anquises, son "ficcións do eu".

Voltemos atrás: vimos como en "Umha mensagem da Dogaresa" a ollada namorada e fascinada do home mitifica a muller real:

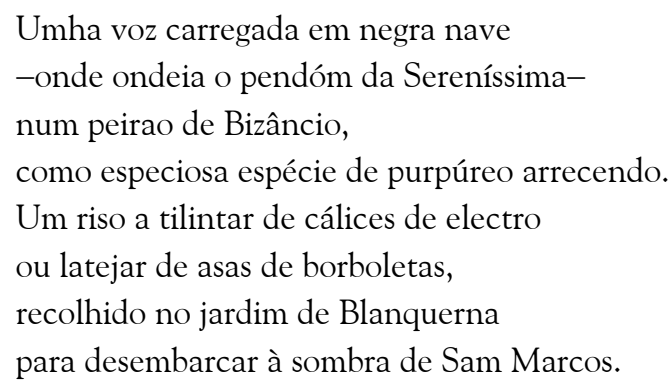

(1986, pp. 125-126)

Mais o que así fala, o poeta que previamente se dirixe a nós para negar ser un novo D’Annunzio, é tamén un ironista, "leva unha dobre vida" (Carson): nunha habita o mundo mítico da Dogaresa; na outra é perfeitamente consciente do mecanismo mental que desencadeou a mitificación:

O meu teléfono tem forma de gôndola.

(1986, pp. 125)

\section{CODA}

En "O meu cavalo piafa no curro do castelo" (Cantigas de amigo e outros poemas) un cabaleiro, non sabemos se xermánico, helénico ou artúrico, disponse a cabalgar polas selvas de Brocelandia e Venusberg. Talvez o faga polas dúas a un tempo, na acronía e na abolición das fronteiras espaciais que o mito posibilita, que só no mito existen. Será entón só personaxe dun soño?:

Montarei a besta de ardentes narinas, em procura do cálice e a donzela, a despeito do anao e o dragom. 
É todo um sonho? Som umha personagem

de um lais que sobre o pó traça a pesunha equina?

Olho os olhos fosfóricos onde arde a luz de um deus, de um demo, de umha força inumana e fatídica.

Um corno de unicórnio sobre a chapa metálica defende a sua testa que abala como a onda.

A sua garupa inquieta

sofre o aguillom da vespa da saudade

de mármore imortal de deusa ou fada que

raptada transportei eu do seu mundo ao nosso?

Meu Pegaso de guerra e aventura,

de fugida e de ensonho, de trampa e de cartom.

Já coas rédeas na mam, já co pé na estribeira,

perderei-me na terra de lume além da cal

Brunilda ou Átropos brindam-me as suas núpcias.

O meu cavalo piafa na beira do infinito.

(1986, p. 108)

Que cabaleiro é este, nunha terra céltica, grega e xermánica, a achegarse ao infinito sobre un "Pegaso de guerra e aventura" que é tamén "de trampa e de cartom"? Personaxe dun soño, ficción dun eu que se soña personaxe a cabalgar por un mundo sen lindes: o do mito. Tristán, Lancelot, Aquiles, Ulises, Belkis, Anquises: facianas múltiplas dun eu que para sobreviver transita do noso universo ao deles.

\section{REFERENCIAS BIBLIOGRÁFICAS}

Blanco, Carmen (2020). Conversas con Ricardo Carballo Calero. 2ª ed. Vigo: Galaxia.

Carson, Anne (2019). La belleza del marido. Un ensayo narrativo en 29 tangos. Barcelona: Lumen.

Carrère, Emmanuel (2020). Yoga. Barcelona: Anagrama.

Carballo Calero, Ricardo (1931). Vieiros. A Coruña: Nós.

Carballo Calero, Ricardo (1934). O silenzo axionllado (1931-1934). Santiago de Compostela: Nós.

Carvalho Calero, Ricardo (1980). Pretérito imperfeito (1927-1961). Sada: Ediciós do Castro. 
Carvalho Calero, Ricardo (1982). Futuro condicional (1961-1980). Sada: Ediciós do Castro.

Carvalho Calero, Ricardo (1984). Narrativa completa. Sada: Ediciós do Castro.

Carvalho Calero, Ricardo (1986). Cantigas de amigo e outros poemas, 1980-1985. A Coruña: Associaçom Galega da Língua.

Carvalho Calero, Ricardo (1990). Reticências... (1986-1989). Sada: Ediciós do Castro.

Fernán-Vello, Miguel A. e Pillado Mayor, Francisco (1986). Conversas en Compostela con Carballo Calero. Barcelona: Sotelo Blanco.

Jankelevitch, Wladimir (1982). La ironía. Madrid: Taurus.

Marco, Aurora (1992). Foula e ronsel. Os anos xuvenis de Carvalho Calero (19101941). Lugo: Fundación Caixa Galicia.

Quiroga, Carlos (2020). Verdadeiro poeta foi - ou a poesia é demasiado séria. En: Francisco Cidrás, ed. Ricardo Carvalho Calero. As formas do compromiso. Santiago de Compostela: Universidade de Santiago de Compostela, 117-145.

Salinas Portugal, Francisco (2020). Voz e silencio. Entrevista con Ricardo Carvalho Calero. Santiago de Compostela: Laiovento.

Villanueva, Darío (2020). Scórpio, autoficción contra posliteratura. En: Francisco Cidrás, ed. Ricardo Carvalho Calero. As formas do compromiso. Santiago de Compostela: Universidade de Santiago de Compostela, 147-166. 